\title{
Combining biotechnology with circular bioeconomy: From poultry, swine, cattle, brewery, dairy and urban wastewaters to biohydrogen
}

\author{
Alice Ferreira ${ }^{\mathrm{a}}$, Paula Marques ${ }^{\mathrm{a}}$, Belina Ribeiro ${ }^{\mathrm{a}}$, Paula Assemany ${ }^{\mathrm{b}}$, \\ Henrique Vieira de Mendonça ${ }^{c}$, Ana Barata ${ }^{a}$, Ana Cristina Oliveira ${ }^{a}$, Alberto Reis ${ }^{a}$, \\ Helena M. Pinheiro ${ }^{\mathrm{d}}$, Luisa Gouveia ${ }^{\mathrm{a}, *}$ \\ ${ }^{\text {a }}$ LNEG, National Laboratory of Energy and Geology I.P. /Bioenergy Unit, Estrada do Paço do Lumiar 22, 1649-038 Lisbon, Portugal \\ ${ }^{\mathrm{b}}$ Federal University of Viçosa/Civil Department, Avenida PH Rolfs s/n, 36570-900 Viçosa, MG, Brazil \\ ${ }^{c}$ Federal University of Juiz de Fora (UFJF), Institute of Biological Sciences, Campus São Pedro, 36036-900, Juiz de Fora, MG, Brazil

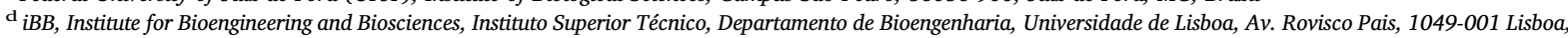 \\ Portugal
}

\section{A R T I C L E I N F O}

\section{Keywords:}

Wastewater bioremediation

Scenedesmus obliquus

Enterobacter aerogenes

Dark Fermentation

Biohydrogen

\begin{abstract}
A B S T R A C T
The ability of microalgae to grow in nutrient-rich environments and to accumulate nutrients from wastewaters (WW) makes them attractive for the sustainable and low-cost treatment of WW. The valuable biomass produced can be further used for the generation of bioenergy, animal feed, fertilizers, and biopolymers, among others. In this study, Scenedesmus obliquus was able to remove nutrients from different wastewaters (poultry, swine and cattle breeding, brewery and dairy industries, and urban) with removal ranges of 95-100\% for nitrogen, 63-99\% for phosphorus and $48-70 \%$ for chemical oxygen demand. The biomass productivity using wastewaters was higher (except for poultry) than in synthetic medium (Bristol), the highest value being obtained in brewery wastewater (1025 mg/(L.day) of freeze-dried biomass). The produced biomass contained 31-53\% of proteins, $12-36 \%$ of sugars and $8-23 \%$ of lipids, regardless of the type of wastewater.

The potential of the produced Scenedesmus obliquus biomass for the generation of $\mathrm{BioH}_{2}$ through batch dark fermentation processes with Enterobacter aerogenes was evaluated. The obtained yields ranged, in $\mathrm{mL}_{2} / \mathrm{g}$ Volatile Solids (VS), from 50.1 for biomass from anaerobically digested cattle WW to 390 for swine WW, whereas the yield with biomass cultivated in Bristol medium was $57.6 \mathrm{~mL} \mathrm{H}_{2} / \mathrm{g}_{\mathrm{vs}}$.
\end{abstract}

\section{Introduction}

Wastewater management is an increasing concern worldwide due to the growing population and industrialization. The uncontrolled discharge of domestic and industrial wastewaters into the environment results in serious pollution problems, making wastewater treatment a mandatory process (Posadas et al., 2015).

Many industries produce a huge amount of wastewater in their processes, namely the food processing industry. In particular, the effluents derived from the dairy and brewery sectors are rich in organic compounds, such as proteins, as well as in phosphates, ammonia and/or nitrate (Raposo et al., 2010). Slaughterhouses generate large volumes of wastewaters, which are characterized by high organic (e.g. residual blood, skin, fat, manure, etc.) and nutrient loads. These industries are intense water consumption activities, generating large volumes of wastewaters (Table 1), containing high loads of organics and nutrients that need to be removed before they can be discharged into the environment. Due to their characteristics, these industrial wastes are a suitable cultivation medium for mixotrophic microalgae, with carbon/ nitrogen $(\mathrm{C} / \mathrm{N})$ and nitrogen/phosphorus $(\mathrm{N} / \mathrm{P})$ ratios favorable for microalgae growth (Maroneze et al., 2014).

Microalgal-bacterial processes have been widely studied for nutrients removal and constitute a cost-effective and sustainable alternative to conventional wastewater treatment technologies due to their potential for cost-free oxygenation and efficient nutrient removal ( $\mathrm{Su}$ et al., 2012, 2011). Microalgae provide, through photosynthesis, the $\mathrm{O}_{2}$ needed by bacteria for the oxidation of organic matter and $\mathrm{NH}_{4}{ }^{+}$. They also consume $\mathrm{NH}_{4}{ }^{+}$in a must faster process than oxidation by bacteria. Simultaneously, the nutrients are assimilated into the algal-bacterial biomass, as a result of their combined auto- and heterotrophic growth.

Abbreviations: bioH $_{2}$, Biohydrogen; COD, Chemical Oxygen Demand; FAME, Fatty Acids Methyl Ester; FM, Fermentation Medium; GC, Gas Chromatography; HRT, Hydraulic Retention Time; TKN, Total Kjehldahl Nitrogen; VS, Volatile Solids; WW, Wastewater

* Corresponding author.

E-mail address: luisa.gouveia@lneg.pt (L. Gouveia). 